\title{
LISTENING SKILLS IN CHILDREN AGED 5-6 YEARS
}

Chrisma Arum Kartikadewi, Siti Wahyuningsih, Warananingtyas Palupi

Universitas Sebelas Maret

chrisma.arumkd@gmail.com

\section{Article History}

accepted 09/07/2018

approved 01/08/2018

published 17/09/2018

\section{Keywords}

ability to listen, music and movement, traditional song, children aged 5-6 years old.

\begin{abstract}
The purpose of this research is to improve the ability to listenthrough the music and movement activity using traditional song. The type of this research is Kurt Lewin model class action research with qualitative data approach and quantitative data. The subjects of this study were children aged 5-6 years in Aulia Surakarta kindergarten in the academic year 2017/2018. Qualitative data validity using source triangulation and method triangulation. Meanwhile, quantitative data validity using construct validation. Data analysis technique using comparation descriptive and interactive model. Result of this research of class activity showed that through music activity and movement using traditional song, the students paid attention to movement and song for 10-15 minutes, the students can repeat the movement when the song is playing again and the students can do the simple verbal instruction from the teacher so that from music activity and movement using traditional song can improve the pay attention ability to the students of children aged 5-6 years in Aulia Surakarta kindergarten in the academic year 2017/2018.
\end{abstract}

Social, Humanities, and Education Studies (SHEs): Conference Series https://jurnal.uns.ac.id/shes

p-ISSN 2620-9284 e-ISSN 2620-9292 


\section{PENDAHULUAN}

Bahasa merupakan bagian dari kehidupan yang harus dikembangkan pada anak usia dini. Konsep bahasa secara menyeluruh telah digunakan pada anak usia dini dalam pengembangan bahasa anak. Wicaksono (2016) menyatakan bahwa sejak usia dini bahasa digunakan oleh anak sebagai alat pengikat sosial, sarana komunikasi dan wadah untuk menyampaikan informasi dan pengalaman anak. Kegiatan berkomunikasi adalah dasar utama pada perkembangan bahasa anak yang meliputi kegiatan menyimak, berbicara, membaca, dan menulis. Pada proses komunikasi melibatkan dua pihak yaitu adanya penyampai pesan dan penerima pesan. Komunikasi dapat berjalan secara efektif apabila informasi yang disampaikan oleh penyampai pesan dapat didengarkan dan dipahami oleh penyimak, sehingga penyimak dapat memberikan tanggapan atau respon sesuai dengan informasi yang disampaikan. Berdasarkan hal tersebut, maka penting bagi anak untuk memiliki kemampuan menyimak yang baik.

Menurut Permendikbud No. 146 tahun 2014 tentang kurikulum 2013 pendidikan anak usia dini mendefinisikan menyimak adalah salah satu perkembangan bahasa selain membaca yang termasuk dalam golongan bahasa reseptif (menerima), yaitu terdiri dari dua indikator yang meliputi: memahami bahasa reseptif (menyimak dan membaca) dan menunjukkan kemampuan berbahasa reseptif (menyimak dan membaca). Asriana (2013) menyebutkan tentang kemampuan bahasa reseptif anak dikembangkan menjadi 2 indikator yaitu anak usia prasekolah dapat mendengarkan bahasa orang lain dan memberikan reaksi atau respon terhadap informasi atau pesan. Selain itu, kemampuan menyimak anak dapat diukur ketika anak memusatkan perhatian dalam jangka waktu 10-15 menit (Wilson \& Korn, 2007). Pendapat lain diungkapkan Adelmann (2012) kemampuan menyimak pada anak dapat dikatakan baik apabila anak dapat melakukan instruksi lisan sederhana yang diberikan oleh guru.

Berdasarkan hasil observasi, kemampuan menyimak pada anak usia 5-6 tahun di TK Aulia Surakarta masih belum berkembang sesuai dengan harapan. Hal tersebut juga dibuktikan dengan hasil pretest yang dinilai dari beberapa indikator yaitu memusatkan perhatian terhadap gerak dan lagu dalam jangka waktu 10-15 menit (Wilson \& Korn, 2007), mengulang gerakan ketika lagu diputar (Asriana, 2013), dan melakukan instruksi sederhana dari guru (Adelmann, 2012). Hasil pretest menunjukkan dari 25 anak terdapat 8 anak $(32 \%)$ yang kemampuan menyimak sudah berkembang dengan baik dan 17 anak (68\%) yang menunjukkan kemampuan menyimak masih belum berkembang secara optimal.

Mengingat pentingnya kemampuan menyimak pada anak usia dini, maka perlu dilakukan tindakan dalam pembelajaran. Peneliti memberikan sebuah solusi untuk dapat mengatasi masalah pada proses pembelajaran khususnya pada kemampuan bahasa anak yaitu kemampuan menyimak anak. Anak usia dini merupakan seseorang yang menyukai kegiatan yang menyenangkan. Kemampuan menyimak pada anak dapat distimulasi dalam pembelajaran melalui kegiatan-kegiatan sederhana yang menarik dan disukai oleh anak, agar anak tidak mudah merasa bosan (Trimulyani, 2013), maka salah satu solusi yang diberikan yaitu melalui kegiatan music and movement dengan menggunakan lagu tradisional.

Musik dan gerak merupakan metode yang sangat berhasil jika digunakan dalam proses belajar bahasa khususnya bagi anak usia dini, karena tahap dalam proses menyimak anak dan kegiatan gerak dan lagu diawali dengan proses mendengarkan dan memperhatikan sumber serta informasi yang diberikan. Hal tersebut didukung oleh pendapat Rachmawati \& Kurniati (2010) yang menyampaikan bahwa kegiatan musik melibatkan kedua belahan otak manusia yaitu otak kiri yang meliputi sistematisasi, kompleksitas, proporsi, dan simetris serta otak kanan yang meliputi imajinasi, kreativitas, dan bahasa, dari pernyataan tersebut maka musik dapat 
mengembangkan kemampuan bahasa anak. Adapun dari segi kegiatan geraknya dapat menarik perhatian anak dan menitipkan pesan bahasa. Menurut Wulandari (2017) gerak merupakan hal penting bagi manusia karena dengan gerak seseorang mampu untuk melakukan komunikasi yaitu dengan menggunakan gerakan yang bermakna sebagai ganti bahasanya.

Jenis lagu yang dapat digunakan dalam kegiatan music and movement adalah lagu tradisional. Seriati \& Hayati (2012) menyebutkan bermain dengan bernyanyi lagu tradisional anak dapat belajar bersosialisasi dengan teman, anak belajar kekompakan, anak belajar mengendalikan diri atau mengendalikan emosi mereka serta belajar mengembangkan kemampuan bahasa dalam masih dalam tahap perkembangan. Sejalan dengan Nurmahanani (2014) bahwa syair lagu tradisional disebut sebagai landas tumpu kemampuan berbahasa anak usia dini, karena lagu tradisional bukan hanya untuk dinyanyikan melainkan disiratkan makna, hakikat dan fungsi syair lagu tersebut.

\section{Kemampuan Menyimak Anak Usia Dini}

Pada usia 5-6 tahun terjadi perkembangan yang cepat dalam kemampuan bahasa anak yang tidak terlepas dari kemampuan menyimak. Jamaris (2006) menyatakan anak usia 5-6 tahun sudah dapat mendengarkan orang lain berbicara dan menanggapi suatu pesan atau informasi tertentu. Tarigan (2008) menyampaikan proses menyimak dilakukan melalui 5 tahapan yaitu, (1) tahap mendengar, (2) tahap memahami, (3) Tahap menginterpretasi, (4) tahap mengevaluasi, (5) tahap menanggapi.

Asriana (2013) menyebutkan tentang kemampuan bahasa reseptif anak yang dikembangkan menjadi 2 indikator yaitu, (1) anak usia prasekolah dapat mendengarkan bahasa orang lain, dan (2) memberikan reaksi atau respon dengan terhadap informasi lisan. Adapun menurut Wilson \& Korn (2007) kemampuan menyimak anak dapat diukur ketika anak memusatkan perhatian dalam jangka waktu 10-15 menit. Selain itu, Adelmann (2012) mengungkapkan pendapatnya bahwa kemampuan menyimak pada anak dapat dikatakan baik apabila anak dapat melakukan instruksi lisan sederhana dari guru. Berdasarkan hal tersebut maka indikator menyimak yang digunakan meliputi (1) anak dapat memusatkan perhatian terhadap gerak dan lagu dalam jangka waktu 10-15 menit, (2) anak dapat mengulang gerakan ketika lagu diputar kembali, dan (3) anak dapat melakukan instruksi lisan sederhana dari guru.

\section{Music And Movement}

Music and movement menurut Trimulyani (2013) adalah kegiatan menikmati lagu yang disertai dengan gerakan anggota tubuh anak. Kegiatan music and movement merupakan kegiatan yang sangat menyenangkan. Djohan (2016) menyampaikan pendapat bahwa salah satu manfaat yang dapat diperoleh melalui musik adalah dalam hal kemahiran berbahasa. Musik dapat memperkaya aspek bahasa, karena pada musik terdapat teks lagu yang akan didengar, dipahami, dan diungkapkan oleh anak. Adapun dari geraknya, kegiatan bergerak dapat disebut dengan bahasa tubuh yang menarik perhatian anak, maka dengan menggunakan aktivitas gerak dapat menitipkan pesan bahasa. Menurut Wulandari (2017) gerak merupakan hal penting bagi manusia karena dengan gerak seseorang mampu untuk melakukan komunikasi, seseorang dapat berkomunikasi dengan menggunakan gerakan yang bermakna sebagai ganti bahasanya.

\section{Lagu Tradisional}

Lagu tradisional dapat disebut juga dengan istilah lagu dolanan anak. Lagu dolanan anak adalah salah satu bentuk lagu Jawa yang digunakan anak-anak dari 
suku Jawa untuk bermain (Wahid \& Saddhono, 2017). Anak-anak pada jaman dahulu biasanya sangat senang menggunakan lagu tradisional pada saat bermain. Menurut Nurmahanani (2014) terdapat manfaat yang didapat dari lagu tradisional karena mengandung makna yang tersirat pada teks lagunya. Syair lagu tradisional disebut sebagai landas tumpu kemampuan berbahasa anak usia dini, karena lagu tradisional bukan hanya untuk dinyanyikan melainkan mengandung isi dan pesan yang harus dipahami dan dimanfaatkan anak-anak usia dini. Pada syair lagu tradisional bukanlah syair lagu itu semata melainkan yang disiratkan adalah makna, hakikat dan fungsi syair lagu itu.

\section{METODE}

Pendekatan penelitian yang digunakan adalah kualitatif dan kuantitatif, jenis penelitian ini adalah penelitian tindakan kelas (PTK) dengan model Kurt Lewin dengan tahapan perencanaan, pelaksanaan tindakan, observasi, dan refleksi. Subjek dari penelitian adalah anak usia 5-6 tahun di TK Aulia Surakarta Tahun Ajaran 2017/2018 yang berjumlah 25 anak dengan 15 anak laki-laki dan 10 anak perempuan.

Sumber data dalam penelitian tindakan kelas ini adalah guru dan anak. Teknik pengumpulan data dilaksanakan melalui observasi, wawancara, tes, dan dokumentasi. Validitas data kualitatif menggunakan triangulasi sumber dan triangulasi metode, sedangkan validitas data kuantitatif menggunakan validitas konstruk. Teknik analisis data yang digunakan adalah analisis data kuantitatif menggunakan deskriptif komparatif dan analisis data kualitatif menggunakan model interaktif yang meliputi pengumpulan data, reduksi data, penyajian data, dan penarikan kesimpulan.

\section{HASIL DAN PEMBAHASAN}

Penelitian tindakan kelas ini dilakukan selama 2 siklus yang terdiri atas 2 pertemuan. Tahap pada setiap pertemuan meliputi perencanaan, pelaksanaan tindakan, observasi, dan refleksi. Pertemuan yang pertama berisi kegiatan music and movement dengan menggunakan lagu Padhang Bulan dan pertemuan kedua menggunakan lagu Suwe Ora Jamu. Indikator yang digunakan untuk menilai kemampuan menyimak anak yaitu memusatkan perhatian terhadap gerak dan lagu dalam jangka waktu 10-15 menit (Wilson \& Korn, 2007), mengulang gerak dan ketika lagu diputar kembali (Asriana, 2013), dan melakukan instruksi lisan sederhana dari guru (Adelmann, 2012). Pada penilaian kemampuan menyimak anak dapat dikatakan tuntas apabila anak telah mencapai berkembang sesuai harapan (BSH) pada setiap aspek indikator kemampuan menyimak. Penelitian akan dikatakan berhasil jika ketuntasan klasikal dapat mencapai $75 \%$ atau lebih dari jumlah anak.

Langkah-langkah kegiatan yang disesuaikan dengan indikator, karena penilaian kemampuan menyimak anak dilakukan pada setiap pertemuan. Berikut merupakan langkah-langkah yang dilakukan pada kegiatan inti:

a. Anak mendengarkan dan memperhatikan lagu tradisional yang akan dinyanyikan oleh guru.

b. Anak menirukan dan mengulang gerakan yang diajarkan guru pada putaran lagu yang selanjutnya.

c. Anak diberikan instruksi lisan sederhana diantaranya anak diberikan perintah untuk menyanyikan lagu tradisional yang diajarkan, anak diberikan perintah untuk melakukan kembali gerak dan menyanyikan lagu, dan anak diberi pertanyaan atau perintah untuk menyebutkan makna dari lagu tradisional.

Pada siklus I menunjukkan hasil persentase penilaian kemampuan menyimak anak secara klasikal sebesar $56 \%$ atau 14 anak tuntas dan sebesar $44 \%$ atau 11 anak belum tuntas. Pada siklus II menunjukkan adanya peningkatan pada kemampuan menyimak anak. Hasil persentase penilaian kemampuan menyimak anak yaitu 
mencapai sebesar $80 \%$ atau sebanyak 20 anak mencapai tuntas dan sebesar $20 \%$ atau sama dengan 5 anak belum mencapai ketuntasan.

Berdasarkan data yang telah diuraikan diatas menunjukkan bahwa dengan menggunakan kegiatan music and movement dapat meningkatkan kemampuan menyimak anak, hal ini sesuai dengan pendapat Asriana (2013) yang menyatakan pendapatnya bahwa anak sangat menyukai kegiatan yang menyenangkan, bernyanyi dan bergerak adalah suatu kegiatan yang disukai anak-anak. Kegiatan gerak dan lagu dapat memudahkan anak untuk mempelajari sesuatu, khususnya pada pemahaman bahasa, maka penerapan gerak dan lagu dapat meningkatkan kemampuan menyimak anak.

Sementara itu, penggunaan lagu tradisional menarik perhatian anak karena anak belum mengenal lagu-lagu yang digunakan masyarakat pada zaman dahulu. Hal ini sejalan dengan pendapat Nurhidayati (2014) bahwa lagu dolanan merupakan salah satu wujud dari budaya Jawa yang adi luhung. Lagu dolanan pada masyarakat Jawa dalam melagukannya disertai dengan suatu permainan, sehingga lagu dolanan sering juga dikelompokkan ke dalam permainan tradisional Jawa. Syair lagu tradisional disebut sebagai landas tumpu kemampuan berbahasa anak usia dini, karena lagu tradisional bukan hanya untuk dinyanyikan melainkan mengandung isi dan pesan yang harus dipahami dan dimanfaatkan anak-anak usia dini (Nurmahanani, 2014).

\section{SIMPULAN}

Berdasarkan hasil penelitian tindakan kelas yang telah dilakukan dalam dua siklus melalui kegiatan music and movement menggunakan lagu tradisional, dapat disimpulkan bahwa penerapan music and movement menggunakan lagu tradisional dapat meningkatkan kemampuan menyimak pada anak usia 5-6 tahun di TK Aulia Surakarta Tahun Ajaran 2017/2018. Aspek yang diukur dalam penelitian tindakan kelas ini meliputi memusatkan perhatian terhadap gerak dan lagu dalam jangka waktu 10-15 menit, mengulang gerakan ketika lagu diputar kembali, dan melakukan instruksi lisan sederhana dari guru. Music and movement menggunakan lagu tradisional merupakan kegiatan yang menyenangkan dan menarik perhatian anak sehingga dapat meningkatkan kemampuan berbahasa anak yaitu pada kemampuan menyimak anak usia 5-6 tahun, sehingga penerapan kegiatan music and movement menggunakan lagu tradisional dapat digunakan dalam pembelajaran sebagai solusi adanya permasalahan yang sejenis.

\section{DAFTAR PUSTAKA}

Adelmann, K. (2012). The Art of Listening in an Educational Perspective Listening reception in the mother tongue. Education Inquiry Journal. Vol. 3 (4):513-534.

Asriana, dkk. (2013). Pengaruh Metode Gerak Dan Lagu Terhadap Kemampuan Menyimak Anak Usia 5-6 Tahun Di Tk Education 21 Kulim Pekanbaru. Jurnal Asriana, 2.

Departemen Pendidikan dan Kebudayaan. (2014). Peraturan Menteri Pendidikan dan Kebudayaan Republik Indonesia Nomor 146 Tahun 2014. Jakarta: Departemen Pendidikan dan Kebudayaan.

Djohan. (2016). Psikologi Musik. Yogyakarta: Penerbit Indonesia Cerdas.

Jamaris, M. (2006). Perkembangan dan Pengembangan Anak Usia Taman Kanakkanak; Pedoman bagi Orangtua dan Guru. Jakarta: PT. Grasindo.

Nurhidayati. (2014). Pelestarian Budaya Jawa Melalui Lagu Dolanan. Jurnal Bahasa dan Seni. 1-15.

Nurmahanani, I. (2014). Syair Lagu Permainan Anak Tradisional Sebagai Landas Tumpu Kemampuan Berbahasa Di Paud. Cakrawala Dini. Vol. 5 (1):20-25. 
Rachmawati, Y. \& Kurniati, E. (2010). Strategi Pengembangan Kreativitas Pada Anak Usia Taman Kanak-Kanak. Jakarta: Kencana Prenada Media Group.

Seriati, N. N. \& Hayati, N. (2012). Permainan Tradisional Jawa Gerak dan Lagu Untuk Menstimulasi Keterampilan Sosial Anak Usia Dini. Jurnal Pendidikan. 1-15.

Tarigan, H. G. (1980). Menyimak Sebagai Suatu Ketrampilan Berbahasa. Bandung: Angkasa.

Trimulyani, R. (2013). Peningkatan Kecerdasan Musikal Melalui Gerak Dan Lagu Menggunakan Lagu Dolanan Tradisional Jawa Pada Anak Kelompok Bermain B Paud 'Aisyiyah Gantiwarno Klaten 2012/2013. Naskah Publikasi Univeritas Muhammadiyah Surakarta, HIm. 1.

Wahid, A. N. \& Saddhono, K. (2017). Ajaran Moral Dalam Lirik Lagu Dolanan Anak. Mudra Jurnal Seni Budaya. Vol. 32 (2): 172-177.

Wicaksono, A., dkk. (2016). Teori Pembelajaran Bahasa (Suatu Catatan Singkat). Yogyakarta: Garidhawaca.

Wilson, K., \& Korn, J. H. (2007). Attention During Lectures: Beyond Ten Minutes. Teaching of Psychology. Vol. 34 (2): 85-89.

Wulandari, R. T. (2017). Pembelajaran Olah Gerak Dan Tari Sebagai Sarana Ekspresi Dan Apresiasi Seni Bagi Anak Usia Dini. Jurnal Pendidikan. 1-18. 